\title{
The Competent Youth's Exposure of Teachers at YouTube.se
}

\author{
Marcus Samuelsson \\ Linköping University Post Print
}

Tweet

N.B.: When citing this work, cite the original article.

Original Publication:

Marcus Samuelsson, The Competent Youth's Exposure of Teachers at YouTube.se, 2011, Youth culture and net culture: online social practices, 243-255.

http://dx.doi.org/

Copyright: 2011 by IGI Global

http://www.igi-global.com

Postprint available at: Linköping University Electronic Press

http://urn.kb.se/resolve?urn=urn:nbn:se:liu:diva-114930 


\section{Youth Culture and Net Culture: \\ Online Social Practices}

Elza Dunkels

Umeå University, Sweden

Gun-Marie Frånberg

Umeå University, Sweden

Camilla Hällgren

Umeå University, Sweden 
Senior Editorial Director:

Director of Book Publications:

Editorial Director:

Acquisitions Editor:

Development Editor:

Production Coordinator:

Typesetters:

Cover Design:
Kristin Klinger

Julia Mosemann

Lindsay Johnston

Erika Carter

Myla Harty

Jamie Snavely

Casey Conapitski \& Deanna Zombro

Nick Newcomer

Published in the United States of America by

Information Science Reference (an imprint of IGI Global)

701 E. Chocolate Avenue

Hershey PA 17033

Tel: 717-533-8845

Fax: 717-533-8661

E-mail: cust@igi-global.com

Web site: http://www.igi-global.com

Copyright (C) 2011 by IGI Global. All rights reserved. No part of this publication may be reproduced, stored or distributed in any form or by any means, electronic or mechanical, including photocopying, without written permission from the publisher. Product or company names used in this set are for identification purposes only. Inclusion of the names of the products or companies does not indicate a claim of ownership by IGI Global of the trademark or registered trademark.

Library of Congress Cataloging-in-Publication Data

Youth culture and net culture : online social practices / Elza Dunkels, Gun-

Marie Frånberg and Camilla Hällgren, editors.

p. cm.

Includes bibliographical references and index.

Summary: "This book engages the complex relationship between technology and

youth culture, while outlining the details of various online social

activities"--Provided by publisher.

ISBN 978-1-60960-209-3 (hardcover) -- ISBN 978-1-60960-211-6 (ebook) 1.

Internet and teenagers. 2. Teenagers--Social networks. 3. Youth--Social

aspects. 4. Technology and youth--Social aspects. 5. Online social networks.

I. Dunkels, Elza, 1960- II. Frånberg, Gun-Marie. III. Hällgren, Camilla, 1973-

HQ799.2.I5.Y667 2011

$004.67^{\prime} 80835--d c 22$

2010050364

British Cataloguing in Publication Data

A Cataloguing in Publication record for this book is available from the British Library.

All work contributed to this book is new, previously-unpublished material. The views expressed in this book are those of the authors, but not necessarily of the publisher. 


\title{
Chapter 14 The Competent Youth's Exposure of Teachers at YouTube.se
}

\author{
Marcus Samuelsson \\ Linköping University, Sweden
}

\begin{abstract}
Swedish children are generally well informed, from preschool all the way through the entire school system, about the meaning of the Convention on the Rights of the Child, CRC (United Nations, 1989), and other similar ideas about their position in relation to adults in school, adults at home and adults in the society. As a result of that experience, almost 30.000 hours in school as an institution, it is possible to argue that a lot of Swedish children, through discussions are well trained to act according to the idea of the competent child. But how do adults, teachers, researchers and journalists react when competent youth use their knowledge to expose what they have experienced in school on websites like YouTube? In order to answer such a question this chapter examines two movies of exposed teachers on YouTube. se. These movies, one with an angry teacher and one with a jocular teacher, are subsequently used in order to argue that exposures like these of teachers are reasonable to understand as being made by the competent youth.
\end{abstract}

\section{INTRODUCTION}

Schools and the events going on during ordinary lessons have in one sense, at least in the western society where school buildings exist, been closed from direct insight until the Internet exploded during the 1990s. Even so youth, parents, teachers, headmasters, authors as well as news media

DOI: $10.4018 / 978-1-60960-209-3 . \operatorname{ch} 014$ have been aware of some of the doubtful things that happen in certain classrooms, as part of certain teachers' ways of managing their work behind closed classroom doors. Many teachers and headmasters previously used to look the other way. They were so to speak, able to turn their back at children's, youth's and in some cases parent's stories about what was going on at the lessons in school. This phenomenon has earlier been described as an example of teachers' ethical 
dilemmas, called the collegial paradox (Colnerud, 1997; 2002). The collegial paradox was shown in such a way that teachers constructed silent alliances with each other when doubtful rumours or accusations, mostly from offended students, where exposed. By doing that, they took sides for their colleagues against the students, even if they knew that there was no smoke without fire. But, teachers and headmasters who recently used to turn a blind eye when other teachers' behaviours towards children or youth opposed for example Convention on the Rights of the Child, CRC (United Nations, 1989), Lärares Yrkesetik, LY (Lärarförbundet \& Lärarnas Riksförbund, 2002) or a legislation such as The Child Protection Law, TCPL from 1 of April 2006 are nowadays forced to react one way or another, as a consequence of witnesses of teachers' violations that are to be found in movies at different websites. The growth of Internet that started 20 years ago has, together with the development of mobile phones, especially the new techniques for sound recording and filming, challenged the until now more or less closed school system. One of the latest, but possibly not the last, ways of obtaining insight in great parts of youth institutionalized school life (Sigsgaard, 1992; Samuelsson, 2008) was the introduction of websites as YouTube.com in February 2005 and later on YouTube.se in October 2008.

The amount of movies exposing teachers' classroom leadership during 2008-2009 where described as a major problem for the teacher profession

One out of twenty teachers has during the last twelve month period sometime been harassed in relation to his or her occupation by being registered with a mobile phone. (Lärarnas Riksförbund, 2008, p. 5)

The same evaluation reported that as many as eleven out of hundred answered that they knew another teacher who during the last twelve month period had been harassed on the Internet.
According to such experiences it is quite easy to understand that teachers feel as if their hands are tied in such a way that they were, or became, afraid to interfere and as a consequence of that perhaps where filmed and later on exposed on websites like YouTube. Almost the same conclusions were drawn by Honawar (2007) from interviews with teachers in USA. The general council for the American Federation of Teachers said that fear of being taped could change how teachers interact with students and is therefore "disturbing to the educational process" (Honawar, 2007, p. 2). Another consequence, according to the general council was that the whole environment could be affected.

Now, concern is growing among teacher advocates that the proliferation of such videos is causing stress among teachers and some students, and could have a chilling effect on classroom discussions. (Honowar, 2007, p. 2)

Such an experience can affect the classroom situation as well as teachers' ways of managing the classroom. Woolfolk Hoy and Weinstein (2006) suggest that students' and teachers' beliefs in good classroom management can be seen as opposite conceptions. For students good classroom management was built up around a

Fair and reasonable system of classroom rules and procedures that protect and respect students. Teachers are expected to care for the students, their learning and their personal lives, before the students will respect and cooperate with the teachers. (Woolfolk Hoy \& Weinstein, 2006, p. 209)

Students didn't mind differential treatment and they wanted, as long as there were no classism, favoritism, racism or sexism, teachers to maintain order without punishment while teachers seemed to believe that students needed to earn their concern, interest, respect and relationship as well as their caring. 
Choices and autonomy support come with successful self-regulation and not before. And some teachers believe that being "mean" may be necessary, in the beginning at least, to establish authority-don't smile until Christmas. (Woolfolk Hoy \& Weinstein, 2006, p. 209)

As Sheets and Gay (1996) stated, it is possible to describe these contrasting views as a downward spiral of mistrust where students only start cooperating first when the teacher has earned it and the teacher withholds their caring until the students have earned it.

In this chapter I aim, with this knowledge in mind, to problematize how the content of movies of teachers at websites such as YouTube.se could be understood. The starting point of such a problematization is an interpretation (Kvale 1997). Using an interpretation one could argue that the exposure could be understood as an act of the competent youth. Such an interpretation could perhaps be understood as provocative since it challenges a great part of the news media and teacher unions' discourse about the phenomena. Regardless of that I start by describing what kind of movies of teachers are to be found at YouTube. se. Next, I provide a description of the content in the movies with different sorts of teachers. This is followed by a discussion where the result is discussed in the light of the idea of the competent youth. The chapter is finally concluded with some implications where I argue for some lessons that teachers and people working in school, as well as adults could learn from the interpretations made in this chapter.

\section{ADOPTING NEW LOGICS AND BEHAVING PROVOCATIVELY}

In order to understand the content of this chapter it is important to also bear in mind that YouTube was first launched as a way of exposing the creators of different kinds of movies. Exposure on websites in general and YouTube specifically is, as the logo says Broadcast Yourself. It's about the directors showing themselves through the movies they have uncovered on the website. On the basis of this it is reasonable to understand that youth as digital natives (Prensky, 2001) or internet natives (Dunkels, 2005) would not exclude classrooms, schools or teachers as phenomena interesting enough to record and expose on YouTube. A second function of websites like YouTube has to do with the different sorts of movies that are found. Movies on YouTube could be categorized according to two sorts of logics: entertainment or enlightenment.

An ordinary search at YouTube showed many examples of all entertainment logics. Through further and more sensible searches examples of enlightenment logics were also found. A recently exposed example of the first enlightenment logic, namely give publicity to unfairness was possible to take part of in November 2009 when Russian policeman Alexsej Dymovskij revealed a video where he spoke of experienced corruption among the Russian police force and demanded that Russia's Prime Minister Vladimir Putin would do something. In less than a week the movie was seen by 700.000 visitors on YouTube. Examples of the second enlightenment logic, i.e. illustrations of role models are movies from television productions like Britain's Got Talent, where Paul Potts and later on Susan Boyle were exposed. Through examples like these youth are, over and over again, taught how effective websites like YouTube are

Table 1. Exposing logics for YouTube movies

\begin{tabular}{|l|}
\hline Logic Category \\
\hline Entertainment Disadvantage of others \\
\hline Irony \\
\hline Self-exposing \\
\hline Enlightenment Give publicity to unfairness \\
\hline Illustrations of role models \\
\hline Protecting oneself \\
\hline
\end{tabular}


in attending to problems as well as showing good examples. A well-known example of the third enlightenment logic - protecting oneself are the snapshots that were taken by the prison guard Charles Graner at Abu Ghraib prison showing him and other female soldiers such as Lynndie England offending Iraqi prisoners (Gourevitch \& Morris, 2008s) i.e. that youth through websites like YouTube are given a new arena to use in order to affect and establish changes in the bigger perspective all over the world and in the smaller perspective in the classroom and at school.

Teachers' experiences of websites like YouTube are described by Honawar (2007) who stated that English-based websites exposed angry teachers as well as enthusiastic teachers. Honowar continues and reports from several interviews with teachers from different parts of USA who find it unpleasant to see small parts, sequences of their up to 45 minutes long lessons grow out of context and later on be presented for a worldwide public. As a way to handle such a phenomenon one of the interviewed teachers said that he, once in a while, checked the web in order to find out if he had been exposed in any kind of movies. Brown (2007) found out that Canadian teachers unanimously had voted for creating a national policy on how cell-phones were to be used in schools and how students who hurt someone's feelings, students or teachers, should be punished. The background for this was that

Cyberbullying in all its forms, from Facebook insults to YouTube ambushes, has skyrocketed in recent months to become the number one nonacademic problem facing classroom today, says CTA [Canadian Teachers' Federation] Winston Carter. (Brown, 2007, July 14).

Honawar (2007) meant that there was a tendency in USA for that as well

School districts tend to ignore videos that are simply embarrassing to a teacher, but do act when they find that the taping is a threat to the school or teacher or is disruptive to learning. (Honawar, 2007, p. 4)

In 2006, The Professional Association of Teachers in England went so far that as demanding that YouTube should be forbidden since the responsible company encouraged net bullying (Honowar, 2007). Another aspect was found in Canada where four students were expelled from school after spreading a video of a teacher scolding a student. The other way round was described in an article by Pickett and Thomas (2006, p. 41) describing how a teacher in USA was dismissed as a consequence of saying to the students that "you are a bunch of [replaced word]".

Research like the above seem to focus on the problems with new technique such as cell-phones and websites while others (Barack, 2007) report about several educational debaters who highlights the possibilities rather than the threats of new technology. One of them depicts about cell-phones: "Eventually they'll be like pencils. No different" (Barack, 2007, p. 1). The same former teacher continues by saying

Schools need to reconsider their perspective on cell phones. They're potentially a powerful tool for collaborative learning. (Barack, 2007, p. 2)

Similar arguments were expressed by the chairman of the Unicef UK and the educational think tank Futurelab who warned that

Technology-savvy children were switching off and becoming 'emotional truants' because schools were not relevant in a digital age. (Milne, 2008, p. 1)

Asimilar description is found in Shuler (2009) who describes how digital and mobile technologies are changing young people's knowledge and ideas about learning outside the classroom while they experience that "none of that expertise or 
engagement currently has currency inside the classroom" (Shuler, 2009, p. 21).

\section{THE COMPETENT CHILD AS PART OF THE YOUTH CULTURE}

Twenty years ago the Convention on the Rights of the Child, CRC (United Nations, 1989), was ratified. The convention was later on followed by expanded focus on different sorts of children's perspective. As a part of such a focus, a broader perspective on research and thinking developed the ideas of the competent child, a contemporary representation where the child is seen as reflexive, autonomous and robust (Alanen, 1992; Prout \& James, 1997; Brembeck, Johansson \& Kampman, 2004) The conception of the competent child has since $C R C$ was ratified been developed in both child culture research as well as in educational research. Brembeck, Johansson \& Kampmann (2004, p. 7) argue that "the idea of the competent child is a fundamental part of the modernity project in most Nordic countries, relating to modern institutions". Even so, children and youth, being seen as immature are often thought of as different from those who are mature, like the difference between those who educate and bring up and those who are educated and brought up (Brembeck, Johansson \& Kampman, 2004).

On the contrary, the fast changes in the lives of today's children and in the notions of children as competent have caused a certain amount of turbulence. (Brembeck, Johansson \& Kampman, 2004, pp. 19-20)

In relation to facts like these, Brembeck, Johansson and Kampman, (2004) mean that today's child who, in her or his own words or acts, is supposed to be able to express "needs" in order to be an autonomous and self-regulating child must be addressed and treated in other ways than children previously were.
Another aspect of the contemporary competent child is discussed by Kryger (2004) who reminds us not to forget some of the elements of the term lifelong learning. According to this idea the learners are supposed to design their own routes, where learning is seen as a never ending process, "at one's own risk and one's own responsibility" (Kryger, 2004, p. 155). In this learning the teacher becomes more of a facilitator, a grown up helper, than an ordinary teacher while the flexible citizen is created. As a consequence of that children are more or less seen as entrepreneurs, shaping their own learning pathways.

In relation to such an approach it is important to remember that a lot of Swedish children go to pre-, primary and secondary schools where placards such as Jäntelagen (Palm, 2000), an antonym to Jantelagen by Sandemose (1968), are nailed to the walls or on bulletin boards:

You shall believe that you are something

1. You shall believe that you are something.

2. You shall believe that you are as good as others and that everyone else are as good as you.

3. You shall believe that you are as wise as others, and sometimes wiser.

4. You shall know that you are as good as others. Knowing that you did your best gives you an opportunity to appreciate those who are better.

\section{Sometimes you know more than others.}

6. You are not more than others but you are outstanding like others. 
7. You are good enough.

\section{Laugh atyourselfand your world, itreleases you.}

9. You shall believe that people care about you.

10. You shall believe that you can teach others quite a lot and that you can learn from others.

11. Why? Because you are someone, one who is needed.

Placards like these work beneficiary to help a lot of Swedish children from early ages to learn about their rights as well as learning about parents' and teachers' restrictions for behaving one way or the other towards them.

Besides these parts of ordinary school life and teaching, younger and younger children are given mobile phones (Frietas \& Buckenmeyer, 2009) not seldom so that their parents are able to reach them whenever or for whatever reason they need to, but also, especially for youth, in order to protect themselves, among other things through ICE: In Case of Emergency (Medierådet, 2007) numbers on their mobile phones. Parents and several nongovernmental organizations such as for example (Friends, 2009) and recently reported research such as (Livingstone and Haddon, 2009) put great effort in teaching youth about accurate risk calculations in daily life as well as on the Internet in order to prepare them for the contemporary society.

The youth of today can therefore be described as on the one hand well aware of their rights, throughout information and discussions (Elvstrand, 2009), but on the other hand greatly depending on adults in home and at school. Even so most youth are in good shape to recognize and put up a fight towards unfairness and last but not least through websites like YouTube given effective tools to share their experience with others.

\section{WHAT KIND OF TEACHERS ARE EXPOSED ON YOUTUBE}

One aim for this chapter is to describe the variations of movies supposed to be found on YouTube.se that expose Swedish teachers. For such a reason I conducted several hours of watching movies at YouTube.se connected to the Swedish word for teacher, lärare. The purpose was, irrespective of when the searches were conducted, to search for an understanding of the movies. It was also to become familiar with the context and the logics of YouTube. My approach was inspired by Ethnographic content analysisAltheide (1987). He argues that "Ethnographic content analysis is used to document and understand the communication of meaning, as well as to verify theoretical relationships" (Althiede, 1987, p. 68). He also states that the researcher during the process continuously tries to change and develop the themes growing out of the analysis.

ECA consists of reflexive movement between concept development, sampling, data collection, data coding, data analysis, and interpretation. The aim is to be systematic and analytic, but not rigid. Although categories and "variables" initially guide the study, others are allowed and expected to emerge throughout the study. Thus, ECA is embedded in constant discovery and constant comparison of relevant situations, settings, styles, images, meanings and nuances. (Altheide, 1987, p. 68)

An immediate result of the search was that there seemed to exist fewer movies with teachers than news media had reported. At the same time I realized how difficult it was to get a grip of the content of the teacher movies. It seemed that YouTube.se was built up around some sort 
of viewer logic, which wasn't always compatible with my research logic. As a result of my first search, December 2008, I found 900 movies. A more recent search, December 2009, got the result of about 2270 movies. During one year the amount of movies was multiplied one and a half times when I used the word teacher. If this is to be seen as an ordinary, big or small change is beyond this chapter's possibility to answer. What can be noted besides the fact of multiplication is that movies with teachers are as old as the website YouTube.com, or in other words, youth embraced the possibilities of using these channels to highlight teachers' ways of behaving while leading the work in classrooms from the beginning. As a result of my searches I have so far found two sorts of movies with teachers; movies showing angry teachers or movies showing jocular teachers. That does not mean that I have watched all the 2270 movies connected with the Swedish word for teacher, lärare. Angry teachers often scolded at the students and made threats against them irrespective of what the student did in the movies. The studied movies with angry teachers showed students in what appeared to be secondary schools or high schools. Jocular teachers sang, danced or laughed with the students in movies that seamed to be from middle school, secondary school as well as high schools. In the same way as in the movies with the angry teachers the jocular teachers seemed to play around irrespective of what the students did at the moment. An important result so far is that it has revealed that a third possible category of teachers' movies is not yet found. That is movies showing ordinary teachers, the reasonably most common teacher that acts in front of students who more or less does their usual schoolwork.

From the description I continued with the ethnographic content analysis by looking at one movie showing an angry teacher and one movie showing a jocular teacher. I scouted for movies that had lots of verbal and nonverbal interaction in order to find out about differences and similarities between movies with an angry teacher and those with a jocular teacher. The movies Anders flipp and Lennart goes wild were selected based on those criteria.

The movie showing the angry teacher, Anders flipp, starts with the camera directed at a male person, through the movie association assumed to be a teacher. The teacher is standing in between a whiteboard and some kind of desk where some books and papers are lying. The teacher is commonly dressed, wearing a light blue shirt and a sweater hanging over his shoulders. Over his head, from the ceiling on top off the room hangs something that looks like a world map and a white screen. Boys and girls mumbling are heard when the male teacher with a forced facial look over his face after two seconds says:

2 Teacher Says: To hell with you, quite simply, I get my damn pay anyway!

6 Teacher Says: Silence, while several students says something inaudible

8 TeacherSays: Bequiet when Iam speaking to you

10 Teacher Says: Don't you understand this is serious, that there is always someone who learns something when we are going through something in a lesson, instead of just sitting and laughing at me, and talking a lot of crap

21 Girl Says: Anders, but are we not allowed to (inaudible)

24 Teacher Interrupts the girl and says: Yes, but you must be quiet anyways 
27 Boy Says: Okay, (inaudible) Girl Says: I am not saying that we should (inaudible)

29 Teacher Interrupts and beats his clenched right hand on his desk while he screams: THERE MUST BE SILENCE

31 TeacherRaises both his fists up over his head before they sink down to the desk

33 Students Talk: A girl says something (inaudible) when a boy says: Lets go, let's go out anyway

35 Teacher Wipes perspiration from under his nose with a finger. Stops for a moment before he shouts out loud: DO YOU NOT

UNDERSTAND WHAT I AM SAYING?

41 Teacher Stands and swings his arms along the side of his body

43 Teacher Watches the students, pointing with his left index finger and says with a loud voice: It's not a damn, it's no damn kindergarten

46 Teacher Takes a book with both his hands and throws it at the desk

47 Teacher Stands still and puts his hands into his pockets
49 Teacher Raises his hands at the side of his head and says: You just babble without stop, dju, dju, dju, dju

51 Teacher Flutters his fingers at the side of his mouth

54 Teacher Says: Words just draining out from you, completely unrestrained, åp, åp, åp, åp while he at the same time gestures with his hands beside his face

\subsection{Students Laughs}

1.03 Teacher Wipes himself on the forehead with his right hand

\subsection{Students Laughs}

\subsection{Teacher Says: All the time (inaudible)}

In this excerpt from the movie Anders flipp we quite directly observe an angry teacher, later on addressed as Anders by the secondary school or high school students. The teacher is standing behind his desk and looking out over what seems to be a whole class setting. The camera is during the movie set in a specific place, directed at the teacher. Even so the teacher as well as several students are heard during the movie. The interaction between the teacher and the students as a group starts after two seconds. The direction, teacher - group, teacher- girl or boy are then possible to take part of through out the entire excerpt. While doing this it is important to remember that we know nothing about was has being going on before the teacher's reaction in the movie and we do not know anything about what is to follow after 
the movie ends. What we can observe is that the teacher's tension is reduced during the interaction from the way his voice shift changes during the interaction starting with an expression of anger and a threat of withdrawal of love. This is followed by a demand for the students to be quiet. When the demand doesn't make the students listen, the teacher instead appeals to them to show respect for those who wish to learn. The teacher's appeal can be understood as questioned by a girl. Her question is interrupted by the teacher who clenches his hand in the desk and screams in a high voice. The teacher's scream does not change the students talk and is therefore followed by another scream and a second threat of withdrawal of love. The climax is then to come when the teacher throws a book at his desk. This action seems to change the interaction in the classroom. The teacher's anger decreases while the tension in his body seems to ease off so he manages, in some kind of ordinary way, to perform his work in the classroom. We can also notice the girl, the same at both times according to voice recognition, who tries to calm the teacher while a boy at one time gives response to what the teacher said. Throughout the movie the teacher is the one leading the interaction and only once or twice he actually listens to the students. The questions he during the movie directs to the students can therefore be understood as rhetoric. To summarize, this movie shows a disciplinary teacher scolding his students who, according to what is said by the teacher, act irresponsible during the lesson by not taking him or his teaching seriously. Another way of understanding the content of this movie is to state that it shows some students that make their teacher loose control so he starts to act irresponsible by swearing and scolding them.

The movie showing a jocular teacher, Lennart goes wild, starts with the camera directed at a male teacher who sits behind a table, on which lays several books, papers, two pens and two boxes of some sort in front of a white board. When the movie starts there are laughs heard in the classroom. Beside the teacher there is a bookshelf where some ringbinders and some box files are seen. The teacher is wearing a pair of dark shoes, a pair of dark trousers and a black, brown and white striped rugby sweater. He looks relaxed and smiles during the entire movie. Laughs are heard from male secondary school or high school students in the background, when a boy, suddenly says, directed to the teacher:

2 Boy Says: One cannot be sure of that (inaudible)

3 Teacher Says: No, it is not certain one can see (inaudible)

4 Boy Says: Is there, is there no fly you can hunt then Lennart?

5 Teacher Looks around and says: No I can't see anyone

8 Teacher Points at a pupil in the other part of the room and says: You had, you had problem with one recently

9 Boy Says: Hm, yes, exactly, precisely

11 Teacher Says: well then, lets take up a book

12 Students Laughs loud

13 Teacher Takes up a book over his head, turns from one side of desk to the other and smashes the book down, presses it against the bench and at the same time says: aaaaahhh ... poooff with a smile on his face 
13 Teacher Smiles at the student with the mobile

13 Students Laughs loudly

18 Teacher Puts the book, opened, aside

19 Boy Says: You are on YouTube now, Lennart

19 Students Laughs loudly

20 Teacher Says: Yes, that's nice

\section{Boy Says: (inaudible)}

\section{Teacher Says: Ok let's move on}

In this movie the interaction between the jocular teacher called Lennart and a group of students is quite immediately showed. We then follow how the interaction between the students and the teacher changes second by second. The interaction is introduced by one boy and answered by the teacher. The teacher then answer the second question from the same boy, close to the camera, and address a question to another boy at the opposite part of the classroom. The teacher replies to the answer from that boy and starts to chase the imaginary fly in front of his desk were he sits tight looking relaxed mostly watching the students who are heard quite clearly, through the entire movie. In this movie, as the one above with the angry teacher, we know nothing about what has occurred before the reaction we have seen in the movie and we know nothing about what will follow after the movie has stopped. We therefore know nothing of the reactions from the students as a response to the teacher's positive answer about being exposed at YouTube.se or what follows after he says "Ok let's move on". To summarize, this movie shows interaction between a teacher and some students who seems to be equal parts. The students involve the teacher to play a role in their YouTube movie and the teacher plays his part so well that he can easily bring the students back to work when the imaginative fly is crushed.

\section{THE CONTEMPORARY COMPETENT YOUTH'S EXPOSURES OF TEACHERS ON YOUTUBE.SE}

In this chapter I have described an interpretation (Kvale, 1997) of movies that expose angry teachers as well as jocular teachers on YouTube.se. The results confirm Honowar's (2007) findings. In addition to other earlier research, I also described that a third sort of teacher, the ordinary teacher, perhaps nineteen out of twenty teachers according to an evaluation from (LR, 2008) weren't able to be found exposed on YouTube.se. These new findings, not earlier described at least according to research I have read, supportmy interpretation that the competent youth has less to gain by exposing all sorts of teachers. That is probably because it would be seen by fewer viewers, lead to fewer comments and more importantly, that there is less to learn from such a movie even if those teachers truly follows $C R C$ and acts according to $L Y$. This, in turn, means that this chapter argues that the competent youth upload movies from school on websites such as YouTube.se for particular reasons. I interpret that such a reason could be understood according to the enlightenment logics: Give publicity to unfairness, Illustrations of role models or Protecting oneself. Such a conclusion about the competent youth's way to handle new technology is also useful for teachers to use in order to keep students engaged in schoolwork (Barack, 2007; Brown, 2007; Milne, 2008).

Conclusively it was quite easy to find movies that exposed angry teachers or jocular teachers 
on the website YouTube.se. As a consequence, it could be understood that the contents of those movies offered viewers something for their lifelong learning (Kryger, 2004). Such an interpretation would challenge argumentations made by news media and teacher unions who argue that exposing teachers is to be understood as some of the entertainment logics that I have presented in this chapter. It is reasonable to argue that exposure of angry teachers while they are acting against $C R C$, or $L Y$ follows as a consequence of the ideas youth have been trained through the entire school system. They act so to speak according to the idea of the competent child just as we expect them to do. Such an act is also similar to other examples of whistle blowing (Hedin, Månson \& Tikkanen, 2008) as well as a challenge towards the collegial paradox (Colnerud, 2002). The interpretation of such an exposure could be understood as if the competent youth has much knowledge to gain from the movies of angry teachers crossing some important agreements about how pupils and youth should be treated in school. Youth's use of contemporary technologies, mobile phones and computers in order to confront injustice and protecting themselves starting with things happening in their own classrooms at their own school should be taken seriously according to the downward spiral of mistrust that Sheats \& Gay (2006) described.

Youth's competent ways of acting is not just about revealing unfairness such as those seen in the movies with the angry teachers, it is also about offering alternative ways to act through the examples of the jocular teachers. In this way the competent youth's acts could be understood as if they have recognized that power and threats are less useful in order to change people's way of acting while reinforcements such as encouragement and rewards are more useful in order to change people's way of behavior according to well-established psychological and educational research (Samuelsson, 2008).
Without having any exact numbers this chapter assumes that far more youths than adults take part in movies at websites like YouTube. From such an expectation one could also assume that the movies are most likely made to inform other youths. These youths are through the movies urged to be aware of how they are treated by teachers or other adults in or outside school. They are also urged to take part in how the classroom is managed (Woolfolk Hoy \& Weinstein, 2006).

One could perhaps think that the above discussed viewpoints of the competent youth is frequently described among earlier research connected to the phenomenon that this chapter describe, but as far as I have found that is not the case. Firstly because there seems to be less research done about youth and YouTube connected to the ideas of the competent child and secondly because most of the research that I have found connect youth movies on websites with cyber bullying and mobile phones and thereby becomes quite normative while this chapter tries to be descriptive while offering a qualified support for discussion among teachers and adults as well as youths themselves.

\section{FUTURE RESEARCH DIRECTIONS}

Although this chapter is based upon an interpretation (Kvale, 1997) of watched movies exposed at YouTube.se it would be interesting to interview youths that have exposed teachers on YouTube. I would like to ask them about the reason for their exposure and if they have got any reactions of their behavior as well as of their movies. It would also be interesting to find out more about what kind of experience they have got out of the exposure. Furthermore, what are the possible differences between those who have exposed angry teachers and those who have exposed jocular teachers? Likewise, it would valuable to meet teachers or other adults working in schools that have been exposed on YouTube.se in order 
to hear their stories; what did they feel and what happened after they got aware about the movies that exposed their work. If there are differences between those who have been exposed as angry teachers and those who have been exposed as jocular teachers, what are the specifics of their respective experiences? And how can schools or the society as a whole, work proactive in order to handle these new sorts of phenomena? It would also be interesting to analyze the comments made about some of the movies with angry teachers as well as with jocular teachers. Finally it would be of great interest to find out how both students as well as teachers reacted to my interpretation that exposure of angry teachers as well as of jocular teachers is to be understood as an act of the competent youth.

\section{REFERENCES}

Alanen, L. (1992). Modern Childhood? Exploring the 'Child Question' in sociology. Jyväskylä: University of Jyväskylä.

Altheide, D. (1987). Ethnographic Content Analysis. Qualitative Sociology, 10(1), 65-77. doi:10.1007/BF00988269

Barack, L. (2007). Schools Mute Cellphones: Teachers nationwide hear one ringy-dingy too many. School Library Journal, 10(1), 1-2.

Brembeck, H., Johansson, B., \& Kampman, J. (2004). Beyond the competent child: Exploring contemporary childhoods in the Nordic welfare societies. Fredriksberg, Denmark: Roskilde University Press.

Brown, L. (2007). Cellphone policy needed, teachers says. The Star, July 14, 1-3

Colnerud, G. (1997). I de MÖRKASTE vrårna av skolans värld. Pedagogiska Magasinet, 1(4), 61-65.
Colnerud, G. (2002). Den kollegiala paradoxen. Pedagogiska Magasinet, 4(4), 24-30.

Dunkels, E. (2005). Nätkulturer - vad gör barn och unga på Internet? Tidskrift för lärarutbildning och forskning, 1-2, 41-49.

Elvstrand, H. (2009). Delaktighet $i$ skolans vardagsarbete. Linköping, Sweden: Linköping universitet.

Friends. (2009). Koll på nätet: En bok om att skapa samtal mellan barn, unga och vuxna om nätet. Stockholm, Sweden: Friends.

Frietas, D., \& Buckenmeyer, J.(2009). Cell Phones in American High Schools: 21 st Century Connections. FSC News, January 19, 1-3.

Gourevitch, P., \& Morris, E. (2008). STANDRAD OPERATING PROCEDURE: A WAR STORY. London: Pan Macmillian.

Hedin, U.-C. Månson. S-A., \& Tikkanen, R. (2008). När man måste säga ifrån: Om kritik och whistleblowing $i$ offentliga organisationer. Stockholm, Sweden: Natur och Kultur.

Honowar, V. (2007). Cellphones in Classrooms Land Teachers on Online Video Sites. Education Week, 27(11), 1-12.

Kryger, N. (2004). Childhood and "New Learning" in a Nordic Context. In H. Bremback, B. Johansson, \& J. Kampman (Eds.), Beyond the competent child: Exploring contemporary childhoods in the Nordic welfare societies. (pp. 153-176). Fredriksberg, Denmark: Roskilde University Press.

Kvale, S. (1997). Den kvalitativa forskningsintervjun. Lund, Sweden: Studentlitteratur.

Lärarförbundet., \& Lärarnas Riksförbund.(2002). Lärares Yrkesetik. Stockholm, Sweden: Lärarförbundet, Lärarnas Riksförbund.

Livingstone, S., \& Haddon, L. (2009). EU Kids Online: Final report. London: LSE. 
Medierådet. (2007). Tips till vuxna om barn/ unga och mobiltelefoner. Stockholm, Sweden: Regeringskansliet.

Milne, J. (2008). What have we got to be scared of? Times Educational Supplement, 25(January), 1-5.

Palm, G. (2000). Den svenska högtidsboken. Stockholm, Sweden: En bok för alla.

Pickett, A. D., \& Thomas, C. (2006). Turn OFF That Phone. The American School Board Journal, (April): 40-45.

Prensky, M. (2001). Digital Natives, Digital Immigrants. On the Horizon, 9 (5). New York: NCB University Press

Prout,A., \& James, A. (1997). A new paradigm for the sociology of childhood? Provenance, promise and problems. In James, A., \& Prout, A. (Eds.), Constructing and reconstructing childhood (pp. 7-17). London: Falmer press.

Samuelsson, M. (2008). Att förhålla sig till institutionalisering: Utmanande för såväl lärare som elever. LOCUS, tidskrift för forskning om barn och ungdomar, 3-4(4), 83-99.
Sandemose, A. (1968). Enflykting korsarsittspår. Stockholm, Sweden: Forum.

Sheets, R. H., \& Gay, G. (1996). Student Perceptions ofDisciplinary Conflict in Ethnically Diverse Classrooms. NASSP Bulletin, 80(580), 84-95. doi:10.1177/019263659608058011

Shuler, C. (2009). Pockets of potential: Using Mobile Technologies to Promote Children's Learning. New York: The Joan Ganz Cooney Center at Sesame Workshop.

Sigsgaard, E. (1992). Forholdet mellem menneskesyn, paradigme, forforståelse og data i humanistisk forskning. Nordisk Psykologi, 44(4), 9-19.

United Nations. (1989). Convention on the Rights of the Child, CRC. New York: United Nations.

Woolfolk Hoy, A., \& Weinstein, C. S. (2006). Student and Teacher Perspectives on Classroom Management. In Evertson, C. M., \& Weinstein, C. S. (Eds.), Handbook of Classroom Management: Research, Practice and Contemporary Issues (pp. 181-219). Mahwah, NJ: Lawrence Erlbaum Associates. 